\title{
Meiofauna winners and losers of coastal hypoxia: case study harpacticoid copepods
}

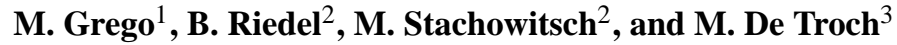 \\ ${ }^{1}$ Marine Biology Station Piran, National Institute of Biology, Fornače 41, 6330 Piran, Slovenia \\ ${ }^{2}$ Department of Limnology and Bio-Oceanography, University of Vienna, Althanstrasse 14, 1090 Vienna, Austria \\ ${ }^{3}$ Marine Biology Section, Ghent University, Krijgslaan 281, Campus Sterre S8, 9000 Ghent, Belgium
}

Correspondence to: M. Grego (grego@mbss.org)

Received: 28 June 2013 - Published in Biogeosciences Discuss.: 23 July 2013

Revised: 25 October 2013 - Accepted: 19 November 2013 - Published: 22 January 2014

\begin{abstract}
The impact of anoxia on meiobenthic copepod species was assessed by means of a field experiment. Four plexiglass chambers were deployed in situ in $24 \mathrm{~m}$ depth to simulate an anoxic event of 9 days, 1 month, 2 months and 10 months. From normoxic to anoxic conditions, we recorded a drop in copepod density and species richness. With increasing duration of anoxia the relative abundance of the individuals of the family Cletodidae increased, and they survived the 1 month and 2 month anoxia, the latter with few specimens. They were the true "winners" of the experimentally induced anoxia. Dominance did not increase in the deployments because not one, but several species from this family were tolerant to anoxia. The overall rate of survival was the same for males and females, but no juvenile stages of copepods survived in anoxia. During a recovery phase of 7 days after a short-term anoxia of 9 days, harpacticoid copepod density did not increase significantly, and there was only a slight increase in species diversity. We concluded that no substantial colonisation from the surrounding sediment took place. The survivors, however, showed a high potential for recovery according to the number of gravid females, whose number increased significantly once the oxygen was available again. These findings imply that substantial energy is allocated to reproduction in the recovery phase.
\end{abstract}

\section{Introduction}

One key threat to the marine interstitial benthos is the shortage of oxygen. Consequently, their vertical distribution is governed by the oxygen penetration into the sediment, and oxygen is considered to be a major structuring factor of metazoan communities in marine sediments (Glud, 2008). With more than 400 oxygen-depleted systems recognised worldwide, covering a total area of $>245000 \mathrm{~km}^{2}$ (Diaz and Rosenberg, 2008), hypoxia (defined here as DO levels $\leq 2 \mathrm{mLL}^{-1}$ ) and anoxia (no oxygen) are amongst the most pressing threats for shallow coastal seas (UNEP, 2006) and thus for the organisms in the sediments.

Benthic organisms are typically classified in two size classes based on the mesh size used to extract them from the sediment. Meiofauna are metazoans that pass through a $1 \mathrm{~mm}$ sieve but are retained on a $38 \mu \mathrm{m}$ sieve, whereas macrofaunal organisms are larger than $1 \mathrm{~mm}$. Beyond this methodological classification they also differ considerably in their functioning and oxygen demand. Meiofauna have lower oxygen requirements and hence are generally more resistant to hypoxia (Giere, 2009). They all lack respiratory organs and thus depend on diffusive oxygen uptake (Wetzel et al., 2001). Consequently, slender, worm-shaped organisms, for example, benefit from a higher surface : volume ratio to gather the required oxygen (Powell, 1989; Wetzel et al., 2001), which is then consumed in the body in seconds (Braeckman et al., 2013).

Within the meiofauna, different levels of sensitivities and tolerances to hypoxia and anoxia have been described. Generally, harpacticoid copepods (Crustacea, Copepoda) are more sensitive to low oxygen concentrations, while nematodes (Nematoda; roundworms) are more tolerant (Vernberg and Coull, 1975; Hicks and Coull, 1983; Murrell and Fleeger, 1989; Wetzel et al., 2001). The latter worm shape benefits from a higher surface : volume ratio (see above). 
Moreover, species-specific responses within copepods and nematodes are reported (Vopel et al., 1998; Modig and Ólafsson, 1998; Wetzel et al., 2001). Thus, an in-depth response study should be based on species-level to accurately interpret the community-level response to hypoxia/anoxia. Furthermore, the local environment, i.e. sediment characteristics or food availability (De Troch et al., 2013), will govern the final response of a benthic community. Hicks and Coull (1983) and Wetzel et al. (2001) suggested that the evolutionary history, i.e. the frequency of hypoxia, might also support the establishment of a more tolerant community, such as the one found in the Skagerrak area (Josefson and Widbom, 1988). This calls for integrating not only the resistance but also the resilience of a community. A holistic approach encompassing the overall meiofauna community effects to hypoxia/anoxia should therefore also include the post-perturbation reactions, i.e. the recovery phase. The individual responses of species will determine "winners" (surviving, more tolerant species) and "losers" (death of sensitive taxa), with the resilience of the survivors being essential for the post-impact community composition. A fast recovery (i.e. weeks) can be achieved through fast reproduction (Harris, 1973; Coull and Vernberg, 1975; Gee and Warwick, 1984), requiring information on often neglected population dynamics.

The present study is designed to provide a more holistic picture of the response of harpacticoid copepods to hypoxia/anoxia in the natural environment. Hypoxia and anoxia were experimentally induced in $24 \mathrm{~m}$ depth in the Gulf of Trieste, northern Adriatic Sea (Mediterranean) with four plexiglass underwater chambers (for details see Stachowitsch et al., 2007). They were deployed for 9 days, 1 month, 2 months and 10 months. Harpacticoid copepods were selected in view of their lowest sensitivity to anoxia. Note that Langlet et al. (2013a, b) analysed the benthic foraminiferans, typically among the most tolerant groups to hypoxia/anoxia, to complement our taxon. Our community analysis is based on species composition and focuses on the individual response of the most resistant species. The hypothesis is that despite their low resistance to hypoxia, harpacticoid copepods show a high resilience. This resilience can be explained by short generation times (Hicks and Coull, 1983; Giere, 2009), low food selectivity in certain species (De Troch et al., 2006) and by an opportunistic nature resulting in fast colonisation (De Troch et al., 2005). These features will enable them to establish a new community as soon as oxygen becomes available again. For this purpose we evaluated copepod community recovery 7 days after the chamber was removed (after the 9 day deployment). Also, we evaluated the population dynamics and sex ratio during the hypoxic/anoxic event as well as during the recovery phase. This yielded additional information on the condition of the survivors, because this copepod community was found to stop feeding during hypoxia (see laboratory experiment in De Troch et al., 2013), although it remained unknown whether they allocate energy to reproduction during low oxygen conditions.

\section{Material and methods}

\subsection{Experimental set-up}

A field experiment was performed on a poorly sorted silty sand bottom in the northern Adriatic Sea (Mediterranean $)\left(45^{\circ} 32.90^{\prime} \mathrm{N} ; 13^{\circ} 33.00^{\prime} \mathrm{E}\right)$ at $24 \mathrm{~m}$ depth. Artificial hypoxia and anoxia were created with four underwater chambers (each $50 \times 50 \times 50 \mathrm{~cm}$ ). While almost all chambers were deployed at the same time, the duration of the respective deployments differed (i.e. 9 days, 1 month, 2 months, 10 months, see below). The chamber used in the 9-day deployment was originally designed to document macro-epifauna and infauna behaviour during oxygen decline (Riedel et al., 2013). The separate lid houses a timelapse camera (images taken in 6 min intervals), 2 flashes, battery packs, a microsensor array (dissolved oxygen, hydrogen sulfide, temperature) plus data logger (Unisense ${ }^{\circledR}$ ). In this deployment, the sensors were positioned $2 \mathrm{~cm}$ above the sediment (measurements taken in $1 \mathrm{~min}$ intervals). For more details on the experimental design see Stachowitsch et al. (2007). The other three chambers were not instrumentequipped. $\mathrm{pH}$ was recorded at the beginning and end of deployments with an external WTW TA 197-pH sensor. All chambers were positioned at macro-epifauna-free sites, without major traces and structures (mounds or pits) that would indicate the presence of larger infauna species. Two to three brittle stars were placed on the sediment inside each chamber to visually better follow and verify the oxygen decline based on their behaviour (Riedel et al., 2008).

A triplicate of normoxic reference cores (length $20 \mathrm{~cm}$, inner $\varnothing=4.6 \mathrm{~cm}$, surface $=16.6 \mathrm{~cm}^{2}$ ) were taken on $3 \mathrm{Au}$ gust 2010. Those samples are referred to as treatment $\mathrm{N}$. Four underwater chambers were deployed, each for a different anoxic duration. Within each chamber, three independent cores, which were at least $10 \mathrm{~cm}$ apart from each other, were taken at the end of each experiment. These cores were treated as replicates. One chamber was deployed on $2 \mathrm{Au}-$ gust 2010 and was sampled on 11 August, namely the 9day anoxic chamber. After this chamber was sampled and removed, the sediment was marked and sampled again (on the intact site triplicate cores were taken) to monitor the recovery on 18 August 2010 (7 days' recovery). The second chamber was deployed on 27 July and sampled on 25 August, namely the 1-month anoxic chamber. The third chamber was deployed on 27 July and sampled on 23 September, namely the 2-month anoxic chamber. Despite the difference in starting and termination points (3 August 2010 vs. 23 September 2010), there was no substantial change in normoxic levels and temperature values measured in a monitoring program every 2 weeks at the same site. The last chamber was deployed on 24 September 2010 and sampled on 5 August of the following year, the 10-month chamber. Those samples are referred to as treatments A9d, R7d, A1m, A2m, A10m. Note that " 9 day, 1 month, 2 months and 10 months" anoxia 
refer to the duration of the entire treatment (i.e. from the day the chamber was closed until samples were taken) and not to the actual duration of anoxia. The deployment times differed by a few days due to practical considerations: depth of the experiment $(24 \mathrm{~m})$, diving constraints (decompression), and boat availability (exception: $10 \mathrm{~m}$ anoxia chamber, deployed several weeks later).

In the A9d-deployment, the oxygen concentration (measured by two oxygen microsensors) started to decrease as soon as the chamber was closed, and anoxia was reached on day 7 (Metzger et al., 2013), two days before the samples were taken. According to geochemical data (Metzger et al., 2013; Koron et al., 2013), anoxia persisted in all the other chambers as well.

\subsection{Copepod extraction and identification}

Meiofauna cores were taken by scuba divers. Three cores were randomly taken outside the chamber (normoxia control treatments, see above) and another three cores were taken inside the chambers before the experiments were terminated (treatments anoxia). Moreover, after short-term anoxia, we followed the short-term recovery and took triplicate cores in the sediment which was re-oxygenated. Cores were immediately transported to the laboratory in cooling boxes and transferred into a thermostatic room with in situ temperature (i.e. $18^{\circ} \mathrm{C}$ ). The cores were sliced in $0.5 \mathrm{~cm}$ intervals for the first $2 \mathrm{~cm}$ and $1 \mathrm{~cm}$ intervals down to $5 \mathrm{~cm}$ depth. The sliced sediment was placed into separate $250 \mathrm{~mL}$ containers.

The overlying seawater from the cores $(10 \mathrm{~mL})$ was added into each $250 \mathrm{~mL}$ container including the sediment slices. The fluorescent CellTracker Green (CTG) label (1 mg stored at $-20^{\circ} \mathrm{C}$ ) was dissolved in $1 \mathrm{~mL}$ dimethyl sulfoxide (DMSO). The final concentration of CTG/DMSO solution was $\sim 1 \mu \mathrm{M}$, corresponding roughly to $\sim 5 \mu \mathrm{L}$ CTG/DSMO per $10 \mathrm{~mL}$ of sediment and liquid together. Overall, $10 \mu \mathrm{L}$ of the CTG/DSMO solution was added to the sedimentoverlying water with a micropipette. The containers were incubated at in situ temperature in the dark for $12 \mathrm{~h}$. Grego et al. (2013) demonstrated that CTG is more accurate to enumerate living meiofauna after anoxia impact than for example Rose Bengal. The samples were subsequently fixed in $4 \%$ borax-buffered $\left(5 \mathrm{~g} \mathrm{~L}^{-1}\right)$ formalin.

The samples were further processed following the standard meiofauna extraction protocol (De Jonge, 1977; Mc Intyre and Warwick, 1984). Formalin-fixed sediment samples were washed with tap water to eliminate formalin and clay by pouring them on a $38 \mu \mathrm{m}$ sieve. The sediment recovered on the $38 \mu \mathrm{m}$ sieve was transferred into $1 \mathrm{dL}$ centrifuges. Levasil ${ }^{\circledR}$ (-distilled water) solution (specific density $=1.17 \mathrm{~g} \mathrm{~cm}^{-3}$ ) was added and gently mixed with the sediment prior to centrifugation. After centrifugation, the copepods were retained in the floating phase and were separated from the sediment phase (containing Foraminifera, see Langlet et al., 2013a, b). As copepods were absent in the deeper sediment layers, only copepods from the uppermost $\mathrm{cm}$ sediment layers $(0-0.5 \mathrm{~cm}, 0.5-1 \mathrm{~cm}, 1-1.5 \mathrm{~cm}$ and $1.5-2 \mathrm{~cm})$ were counted under a binocular (Nikon SMZ 800 with a Nikon INTENSILIGHT C-HGFI for UV production and A 488 filter) and picked out with a needle. CTG samples containing a large number of animals were split into several petri dishes to avoid long exposure of animals to UV light, in order not to lose fluorescence due to bleaching. The specimens were picked out of the sample and then mounted in toto on slides containing glycerol. The species were identified to "working species" and enumerated as sp. 1, sp. 2, etc. within a particular genus (as for example in Janssen et al., 2013).

Species identification was done with an Olympus BX-51 microscope equipped with a drawing tube (main identification features). The copepod reference collection and observation notes with sketches from this study are available at the Marine Biology Station Piran, Slovenia. Identification keys used include (Lang, 1948; Boxshall and Hasley, 2004; Wells, 2007). The different stages (copepodite, male, female, ovigerous female) and number of egg sacs were enumerated.

\subsection{Data analysis}

To test the effect of factor treatment $(\mathrm{N}, \mathrm{A} 9 \mathrm{~d}, \mathrm{R} 7 \mathrm{~d}, \mathrm{~A} 1 \mathrm{~m}$, $\mathrm{A} 2 \mathrm{~m}, \mathrm{~A} 10 \mathrm{~m})$ on copepod density per core $\left(16.6 \mathrm{~cm}^{2}\right.$, depths pooled), a one-way ANOVA was used. The data were first tested for normality with the Kolmogorov-Smirnov test and for homoscedasticity with Levene's test (Sokal, 1995; Dytham, 2003; Zuur et al., 2010). Subsequently, the data on copepod densities were square root transformed, to meet both assumptions, prior to the one-way ANOVA.

To test the distribution of copepods (absolute density) in the respective treatments $(\mathrm{N}, \mathrm{A} 9 \mathrm{~d}, \mathrm{R} 7 \mathrm{~d}, \mathrm{~A} 1 \mathrm{~m}, \mathrm{~A} 2 \mathrm{~m}, \mathrm{~A} 10 \mathrm{~m})$ and different sediment depths $(0-0.5,0.5-1,1-1.5$ and 1.5$2 \mathrm{~cm}$ ), a two-way ANOVA was performed. In order to meet the assumption of normality (Kolmogorov-Smirnov test) and homoscedasticity (Levene's test), data were log-transformed prior to the two-way ANOVA. All tests were performed using the $\mathrm{R}$ statistical software (R Development Core Team, 2011). The graphs were drawn using Microsoft Office Excel and OriginPro 8.

For multivariate analyses and for the calculation of diversity indices, Primer v6 (PRIMER-E, 2006) (Clarke and Warwick, 2001; Clarke and Gorley, 2006) was used. Based on the species densities (untransformed data) the copepod assemblages were analysed for similarity with the Bray-Curtis similarity index. Possible differences among treatments $(\mathrm{N}$, A9d, R7d, A1m, A2m, A10m) were analysed with one-way designed PERMANOVA and PERMDISP tests (Anderson et al., 2008). The similarity among samples was then visualised in the non-metric Multi-Dimensional Scaling (nMDS). A SIMPER analysis was used to investigate which species were responsible for dissimilarities among treatments. Moreover, potential differences among treatments $(\mathrm{N}, \mathrm{A} 9 \mathrm{~d}, \mathrm{R} 7 \mathrm{~d}, \mathrm{~A} 1 \mathrm{~m}$, 


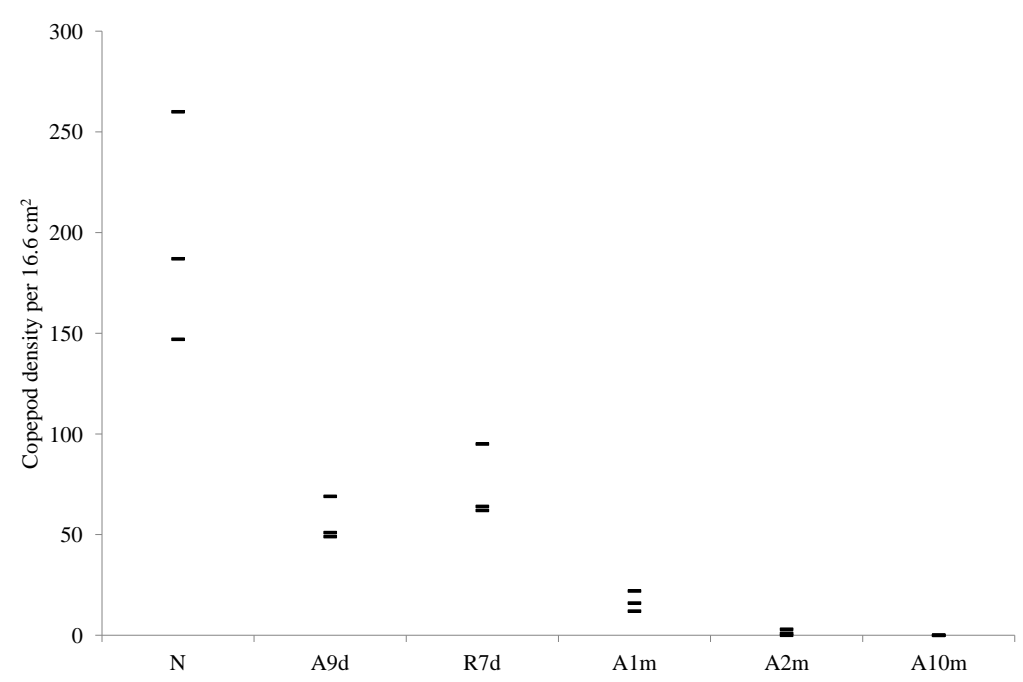

Fig. 1. Absolute copepod densities (ind. per $16.6 \mathrm{~cm}^{-2}$ ) in all samples (pooled depths, copepodites included).

$\mathrm{A} 2 \mathrm{~m}, \mathrm{~A} 10 \mathrm{~m})$ and depth layers $(0-0.5,0.5-1,1-1.5$ and $1.5-$ $2 \mathrm{~cm})$ were further analysed with a two-way crossed PERMANOVA with treatment and depth as fixed factors (Anderson et al., 2008).

A cluster analysis of the copepod species densities per different sediment depth layers (absolute densities, not transformed) was calculated based on Bray-Curtis similarity.

Diversity of the harpacticoid copepod communities was calculated at species levels using three indices: species richness, Shannon diversity index and Pielou's evenness index by means of Primer v6 (Clarke and Warwick, 2001; Clarke and Gorley, 2006). Copepodite (CI-CV) life stages were excluded from the diversity measures.

To test whether the ratio of copepod males vs. females changes from normoxia to different anoxic treatments and in the recovery phase, we analysed the sex ratio with the $G$ test (unplanned test of the homogeneity of replicates tested for goodness of fit; Sokal, 1995).

\section{Results}

\subsection{Copepod assemblage in different oxic conditions}

This study yielded 47 species (overall 1038 individuals identified) of harpacticoids.

The copepod density in the sediment cores was highest in normoxic conditions and gradually dropped with the duration of anoxia (Fig. 1). The density ( \pm STD per $\left.16.6 \mathrm{~cm}^{-2}\right)$ in normoxic samples was significantly higher $(198 \pm 57.3)$ than that in all anoxic samples (A9d: $56.3 \pm 11$; A1m: $16.7 \pm 5$;
A2m: $2 \pm 1.4$, A10m: 0) as well as in the R7d-samples $(73.7 \pm 18.5)$. The one-way ANOVA (factor oxygenation, on square root transformed data) revealed a significant difference $(p<0.001)$ among treatments. The Tukey HSD post hoc tests clarified the pairwise differences, i.e. all combinations were significantly different from each other $(p<0.001$ or $p<0.01$ ) except for A9d-R7d and A1m-A2m. Seven days after termination of the A9d-deployment, potential recolonisation from the surroundings was examined. The similar values of copepod densities in 7 days' recovery and the 9 days' anoxia treatment indicate that no substantial recolonisation took place.

The MDS based on absolute copepod species abundances showed a high similarity among replicates of normoxia (Fig. 2). Similarly, a low spread among the replicates of 9 days' anoxia and 7 days' recovery, respectively, was found (Fig. 2). The 1-month anoxia replicates formed the third group, while the 2-month anoxia replicates were most different from the rest (Fig. 2). The latter showed also more variance among the replicates. Note that one replicate of the 2-month anoxia deployment as well as the 10-month anoxia replicates were not plotted because no live copepods were present. The PERMANOVA test and PERMDISP test (factor treatment; N, A9d, R7d, A1m, A2m, A10m) revealed that the treatments differ significantly from each other $(\mathrm{P}($ perm $)$ $=0.001$ and $\mathrm{P}($ perm $)=0.353$, respectively).

The SIMPER analysis (Table 1) showed the species that contributed most to the dissimilarity among treatments. After short-term anoxia (9 days), the most impacted species were (see average abundance in Table 1) Pseudobradya sp. 2, Heteropsyllus sp. 1, Nitocrella sp. 1 and Longipedia sp. 2. In 


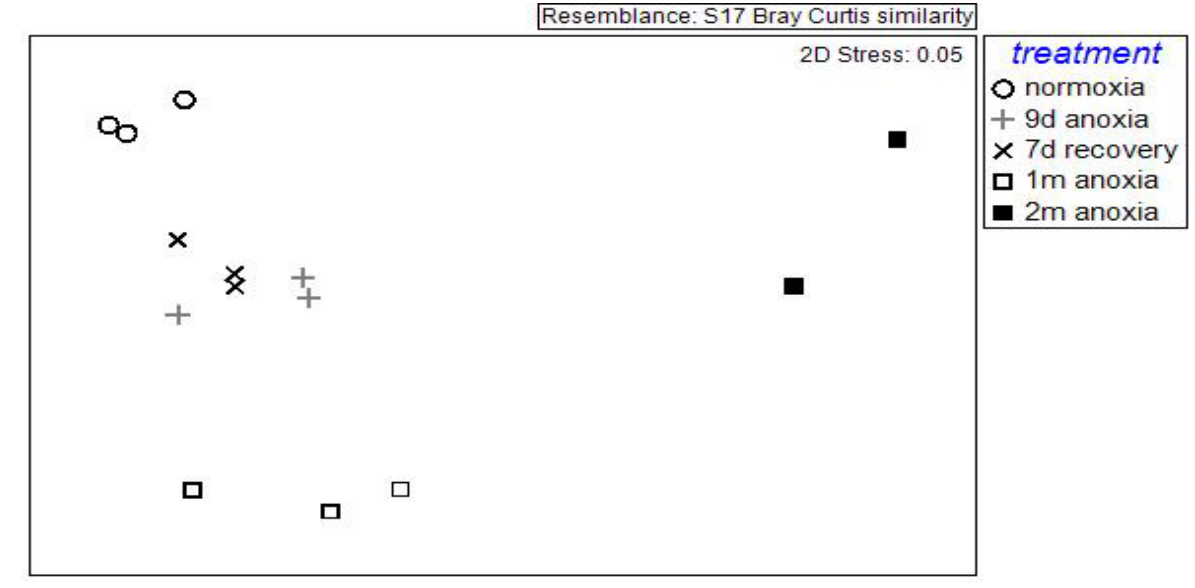

Fig. 2. MDS based on absolute harpacticoid copepod composition (depth pooled, without copepodites).

contrast, the density of Stylicletodes $\mathrm{sp} .2$ was highest after 9 days of anoxia (meiofauna patchiness), whereas the density and the number of six species of the genus Cletodes remained at the same level as in normoxia. With increasing anoxia duration (1 month), however, the number of Stylicletodes sp. 2 and Cletodes sp. 2 drastically dropped. This was also the main reason for the dissimilarity among samples because both species contributed $31.9 \%$ to the dissimilarity with the other treatments. Interestingly, while Acrenhydrosoma sp. 1 and Enhydrosoma sp. 4 were absent from the 9 day anoxic samples, the same species were present in the 1 month anoxia samples. This may reflect the patchiness of meiofauna communities, which might not always (for all species) be assessed with three replicates. Finally, the prolongation of anoxia to 2 months killed most harpacticoid copepods, with individuals of only three species (two Cletodes species, one Enhydrosoma) surviving.

Overall, the number of species decreased significantly ( $p=0.004)$ by half already after short-term (9 days) anoxia (Fig. 3a), and continued decreasing with the prolongation of anoxia. Similarly, the Shannon diversity significantly dropped ( $p<0.001)$; only a slight increase was measured in the 7 days' recovery (Fig. 3b). Interestingly, in all anoxic deployments the evenness index remained stable (Fig. 3c), indicating that any one species never dominated the community.

\subsection{Copepod population composition}

The male/female ratio of copepods did not change significantly from normoxia to anoxia of different duration and in the short recovery treatment ( $G$ test, $p>0.05$ ). The ratio is not balanced, as the relative abundance of females was always higher than that of males (Table 2). In all treatments, including normoxia, the highest number of gravid females was recorded in the family Cletodidae (Table 2). The high values for this family were independent of the relative abundance of the family because the relative share of Cletodidae to the overall community was highly similar to the shares of Ameiridae, Canthocamptidae, Longipedidae, Ectionsomatidae and Miracidae (Fig. 4). Anoxia resulted in a drastic decrease in the number of gravid females in all families (Table 2). The level of reduction corresponded with the increasing duration of oxygen depletion (i.e. greatest drop in $\mathrm{A} 2 \mathrm{~m}$ ). The number of gravid females (mostly family Cletodidae and also some Miraciidae) significantly increased in the 7-day recovery treatment. The ANOVA calculated from the density of gravid females per treatment (triplicated samples) N, A9d, $\mathrm{R} 7 \mathrm{~d}$, and A1m, showed significant differences among treatments $(p<0.001)$, and Tukey HSD revealed that those differences are significant among pairs: $\mathrm{N}$ with all the anoxia treatments, and R7d with all the anoxia treatments.

Likewise, the number of juvenile copepodite stages (IV) dropped drastically (Table 2) with 9 days anoxia, and copepodites were completely absent with lengthier anoxia (1 month, 2 months, 10 months).

\subsection{Copepod assemblage in different depths and oxic conditions}

Based on the copepod density in different sediment layers $(0-0.5,0.5-1,1-1.5$ and $1.5-2 \mathrm{~cm})$ and different treatments (N, A9d, R7d, A1m, A2m, A10m), a two-way ANOVA on logarithmically transformed data showed a significant effect of each factor on density ( $p<0.001$ for factors treatment and depth, and $p=0.0512$ for the interaction of both factors) (Fig. 5).

Moreover, based on species composition, the copepod assemblages in different treatments and at different sediment depths were analysed with a two-way crossed PERMANOVA test and PERMDISP tests. From the tests we cannot formulate any strong conclusion for the individual factors (treatment or depth). Treatment did have an effect, but there is an interaction with depth. This can be explained by the 
Table 1. SIMPER analysis - average abundances of species within a group (treatment) and cumulative contribution to dissimilarity. $\mathrm{N}$ $=$ normoxia, $\mathrm{A}=$ anoxia, duration of treatment: 9 days, 1 month, 2 months.

\begin{tabular}{|c|c|c|c|}
\hline Species & $\begin{array}{r}\text { Group normoxia } \\
\text { Av.Abund }\end{array}$ & $\begin{array}{r}\text { Group 9d anoxia } \\
\text { Av.Abund }\end{array}$ & Cum.\% \\
\hline Pseudobradya sp. 2 & 18 & 1.67 & 10.84 \\
\hline Heteropsyllus sp. 1 & 13.67 & 1.67 & 19.23 \\
\hline Nitocrella sp. 1 & 9.67 & 0.67 & 25.52 \\
\hline Longipedia sp. 2 & 6.33 & 0 & 30.29 \\
\hline Stylicletodes sp. 2 & 3.33 & 9 & 34.76 \\
\hline Normanella sp. 1 & 7.67 & 1.33 & 39.22 \\
\hline Idyanthe sp. 1 & 6.33 & 0 & 43.62 \\
\hline Cletodes sp. 4 & 6.33 & 7 & 47.62 \\
\hline Pseudobradya sp. 1 & 5.67 & 0.33 & 51.2 \\
\hline Stenhelia (Delavalia) sp. 1 & 5 & 0 & 54.76 \\
\hline Asellopsis sp. 1 & 5.67 & 1 & 58.25 \\
\hline Mesochra sp. 1 & 4.67 & 0.33 & 61.15 \\
\hline Cletodes sp. 2 & 7 & 9.33 & 63.83 \\
\hline Proameira sp. 1 & 4 & 0 & 66.51 \\
\hline Ectinosoma sp. 1 & 3.33 & 0 & 69.06 \\
\hline Longipedia sp. 1 & 3.67 & 0 & 71.61 \\
\hline Cletodes sp. 1 & 1 & 4 & 73.7 \\
\hline Ameira sp. 1 & 2.33 & 0 & 75.63 \\
\hline Cletodes sp. 3 & 3.67 & 4.33 & 77.55 \\
\hline Haloschizopera sp. 2 & 4 & 1.33 & 79.47 \\
\hline Robertsonia sp. 1 & 3.67 & 1 & 81.35 \\
\hline Proameira sp. 2 & 2.33 & 0 & 83.04 \\
\hline Rhizothrix sp. 1 & 2.67 & 0.67 & 84.66 \\
\hline Vibriopsyllus sp. 1 & 3 & 1.33 & 86.09 \\
\hline Stylicletodes sp. 1 & 2.33 & 1 & 87.45 \\
\hline Enhydrosoma sp. 2 & 0.33 & 2 & 88.61 \\
\hline Typhlamphiascus sp. 1 & 2 & 1.33 & 89.72 \\
\hline Cletodes sp. 6 & 3 & 2.33 & 90.81 \\
\hline Species & $\begin{array}{r}\text { Group 9d anoxia } \\
\text { Av.Abund }\end{array}$ & $\begin{array}{r}\text { Group } 1 \mathrm{~m} \text { anoxia } \\
\text { Av.Abund }\end{array}$ & Cum.\% \\
\hline Stylicletodes sp. 2 & 9 & 0.33 & 17.86 \\
\hline Cletodes sp. 2 & 9.33 & 2.67 & 31.88 \\
\hline Cletodes sp. 4 & 7 & 2.33 & 41.07 \\
\hline Cletodes sp. 1 & 4 & 0.33 & 48.01 \\
\hline Asellopsis sp. 1 & 1 & 3.33 & 54.17 \\
\hline Enhydrosoma sp. 2 & 2 & 0 & 58.35 \\
\hline Cletodes sp. 6 & 2.33 & 1 & 62.48 \\
\hline Cletodes sp. 3 & 4.33 & 3.33 & 65.96 \\
\hline Enhydrosoma sp. 4 & 0 & 1.67 & 69.3 \\
\hline Pseudobradya sp. 2 & 1.67 & 0 & 72.4 \\
\hline Heteropsyllus sp. 1 & 1.67 & 0 & 75.31 \\
\hline Typhlamphiascus sp. 1 & 1.33 & 0 & 78.04 \\
\hline Vibriopsyllus sp. 1 & 1.33 & 0 & 80.77 \\
\hline Haloschizopera sp. 2 & 1.33 & 0 & 83.32 \\
\hline Normanella sp. 1 & 1.33 & 0.67 & 85.7 \\
\hline Robertsonia sp. 1 & 1 & 0 & 87.88 \\
\hline Acrenhydrosoma sp. 1 & 0 & 1 & 89.98 \\
\hline Stylicletodes sp. 1 & 1 & 0 & 91.62 \\
\hline Species & $\begin{array}{r}\text { Group } 1 \mathrm{~m} \text { anoxia } \\
\text { Av.Abund }\end{array}$ & $\begin{array}{r}\text { Group } 2 \mathrm{~m} \text { anoxia } \\
\text { Av.Abund }\end{array}$ & Cum.\% \\
\hline Cletodes sp. 3 & 3.33 & 0 & 19.13 \\
\hline Asellopsis sp. 1 & 3.33 & 0 & 35.11 \\
\hline Cletodes sp. 4 & 2.33 & 0 & 50.4 \\
\hline Cletodes sp. 2 & 2.67 & 0.5 & 61.1 \\
\hline Enhydrosoma sp. 4 & 1.67 & 0 & 71.17 \\
\hline Acrenhydrosoma sp. 1 & 1 & 0 & 78.32 \\
\hline Cletodes sp. 6 & 1 & 0.5 & 85.28 \\
\hline Enhydrosoma sp. 2 & 0 & 1 & 91.35 \\
\hline
\end{tabular}

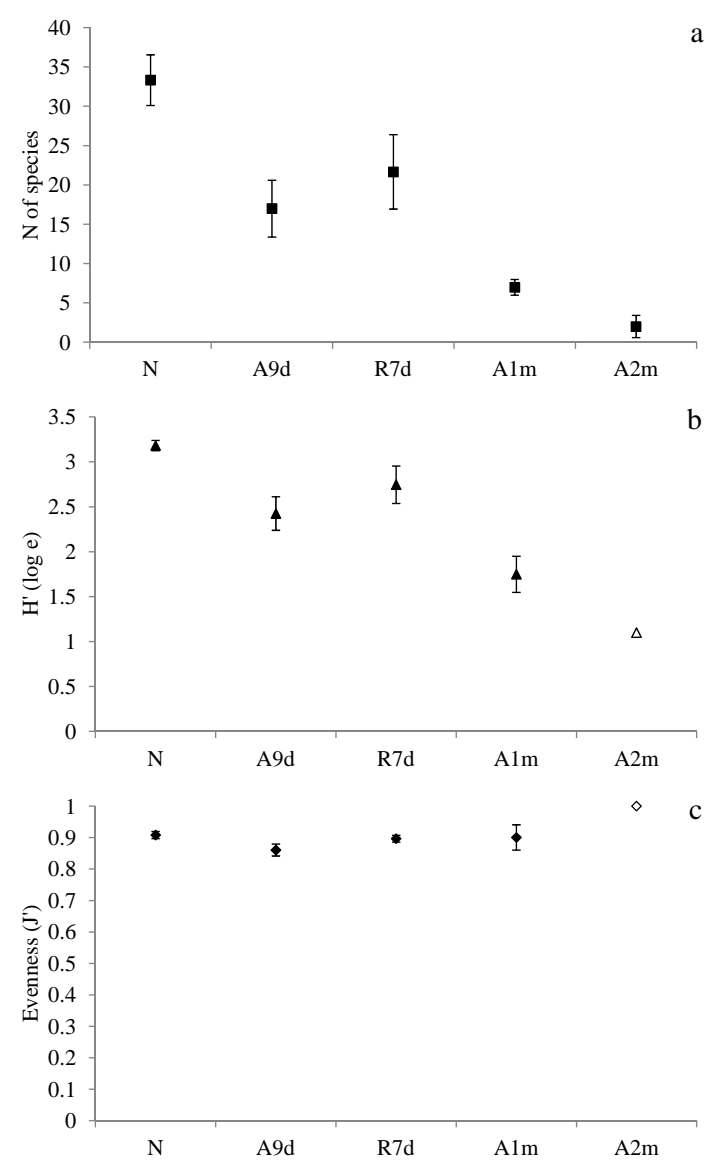

Fig. 3. Diversity indices: (a) species richness; (b) Shannon diversity index (A2m; calculated from one replicate containing 3 specimens, as in the other replicate only a single individual was present); (c) Pielou's evenness index (A2m; same as for Shannon diversity index). Depth was pooled, copepodites excluded from calculations. $\mathrm{N}=$ normoxia, $\mathrm{A}=$ anoxia, $\mathrm{R}=$ recovery, duration of treatment: 7 days, 9 days, 1 month, 2 months.

fact that most of the fauna is concentrated in the top sediment layer.

Four main clusters were defined based on the absolute copepod species composition in the different sediment layers $(0-0.5,0.5-1,1-1.5$ and $1.5-2 \mathrm{~cm})$ (Fig. 6). In the first cluster the most similar were the top layers $(0-0.5 \mathrm{~cm})$ of 9 days' anoxia and 7 days' recovery, which grouped close to the second $(0.5-1 \mathrm{~cm})$ sediment layer of normoxia. The second cluster is formed from deeper layers of 9 days' anoxia, and 7 days' recovery and the top layers of 1-month anoxia. In the last two clusters the remaining deeper sediment layers clustered together with the top layer $(0-0.5 \mathrm{~cm})$ of the longterm (2 months) anoxia sample. 


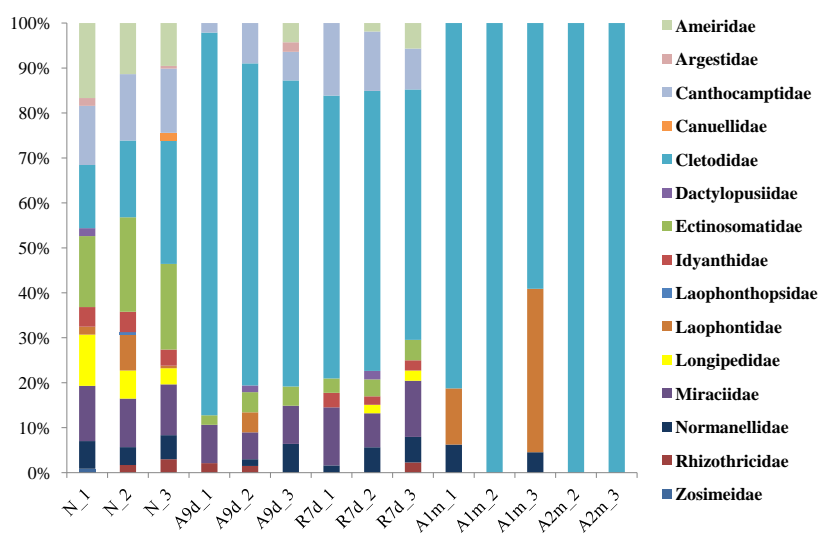

Fig. 4. Relative composition of copepod families in the different replicates (three per treatment, only 2 replicates for the 2-month treatment). $\mathrm{N}=$ normoxia, $\mathrm{A}=$ anoxia, $\mathrm{R}=$ recovery, duration of treatment: 7 days, 9 days, 1 month, 2 months, replicates indicated by $1,2,3$. Families listed alphabetically, and plotted in the column in same order.

Table 2. Number of gravid females (sum of all cores) of various families and number of copepodite stages (sum of all cores), in different treatments. Gravid females were absent in 2-month and 10month anoxia treatments. Relative amount of females (F) and males (M) averaged over three replicates is also given (note in 2-month anoxia calculated from 4 individuals present in two replicates). $\mathrm{N}=$ normoxia, $\mathrm{A}=$ anoxia, $\mathrm{R}=$ recovery, duration of treatment: 7 days, 9 days, 1 month, 2 months.

\begin{tabular}{lccccc}
\hline & Normoxia & Anoxia 9d & Recovery 7d & Anoxia 1m & A2m \\
\hline Ameiridae & 3 & - & 1 & - & - \\
Argestidae & - & - & - & - & - \\
Canthocamptidae & 1 & - & - & - & - \\
Canuellidae & - & - & - & - & - \\
Cletodidae & 15 & 3 & 22 & 2 & - \\
Dactylopusiidae & - & - & - & - & - \\
Ectinosomatidae & 1 & - & - & - & - \\
Ectionsomatidae & 2 & - & - & - & - \\
Idyanthidae & 1 & - & - & - & - \\
Laophonthopsidae & - & - & - & - & - \\
Laophontidae & - & - & - & - & - \\
Longipedidae & 1 & - & - & - & - \\
Miraciidae & 3 & - & 2 & - & - \\
Normanellidae & 1 & - & - & - & - \\
Rhizothricidae & - & - & - & - & - \\
Zosimeidae & - & - & - & - & - \\
\hline copepodites & 135 & 7 & 17 & - & - \\
\hline F(\%) & 0.63 & 0.60 & 0.71 & 0.72 & 0.60 \\
M(\%) & 0.37 & 0.40 & 0.29 & 0.28 & 0.40 \\
\hline
\end{tabular}

\section{Discussion}

This field experiment documents the individual responses of harpacticoid copepod species to anoxia. By including different incubation deployment times, we were able to illustrate, more precisely than ever before in the field, the sensitivity of harpacticoid copepods to oxygen depletion, a recurring event in the Gulf of Trieste (Stachowitsch, 1984, 1991; Faganeli et al., 1991; Justić et al., 1993). Although copepods

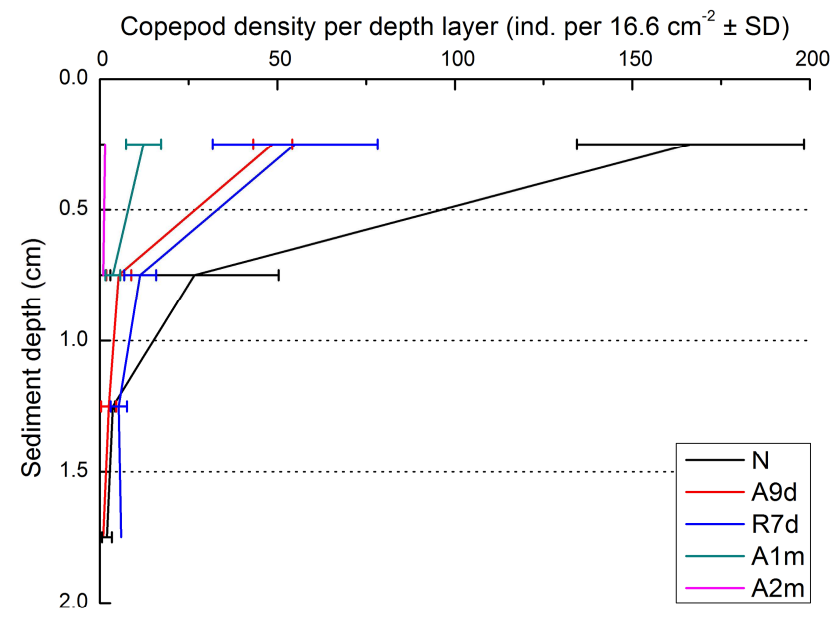

Fig. 5. Average $( \pm S D)$ copepod density (ind. per $16.6 \mathrm{~cm}^{-2}$ ) in four sediment layers $(0-0.5,0.5-1,1-1.5$ and $1.5-2 \mathrm{~cm})$ and in different treatments; $\mathrm{N}=$ normoxia, $\mathrm{A}=$ anoxia, $\mathrm{R}=$ recovery; duration of treatment: 7 days, 9 days, 1 month, 2 months.

are known to be among the most sensitive meiofauna groups to low oxygen concentrations (see review by Wetzel et al., 2001; De Troch et al., 2013), our results show that the densities of harpacticoids dropped considerably after 9 days of anoxia, but that still one-fourth of the community survived. A longer duration of anoxia (up to 2 and 10 months) was necessary to remove almost all specimens. This sheds new light on the anoxia-sensitivity/tolerance of harpacticoid copepods, i.e. they may be less sensitive than generally stated in the literature (Hicks and Coull, 1983; Murrell and Fleeger, 1989; Modig and Ólafsson, 1998; Wetzel et al., 2001). Alternatively, benthic diatoms may have produced enough pulses of oxygen - not recorded by the sensor - to allow a few species to survive the extreme conditions for 1-2 months. Emili et al. (2012) analysed the light penetration through a similar benthic chamber (same size and plexiglass thickness $-0.6 \mathrm{~cm}$ ) and recorded $92 \%$ penetration of photosynthetically active radiation. Those were ideal conditions (and in only ca. $1 \mathrm{~m}$ depth in Marano Lagoon); our chambers, however, were much deeper $(24 \mathrm{~m})$ and soon became shadowed by the sedimented material and animals (e.g. brittle stars) climbing onto them. The initial lack of such shading, however, coupled with primary production, would be one potential explanation of the survival of few copepods in the 2month anoxia treatment. Other strategies, such as the attachment of epibiotic diatoms on the ventral part of the pelagic copepod Acartia italica, have also been forwarded to explain survivals in anoxia (Kršinić et al., 2000).

The flux of pore water nutrients (Koron et al., 2013) points to potential bioturbation activities in normoxic and recovery sediments. The flux measurements in 9 days and 1 month of anoxia also suggest that bioturbation was present especially in the top sediment layers, probably due to vertical migration 


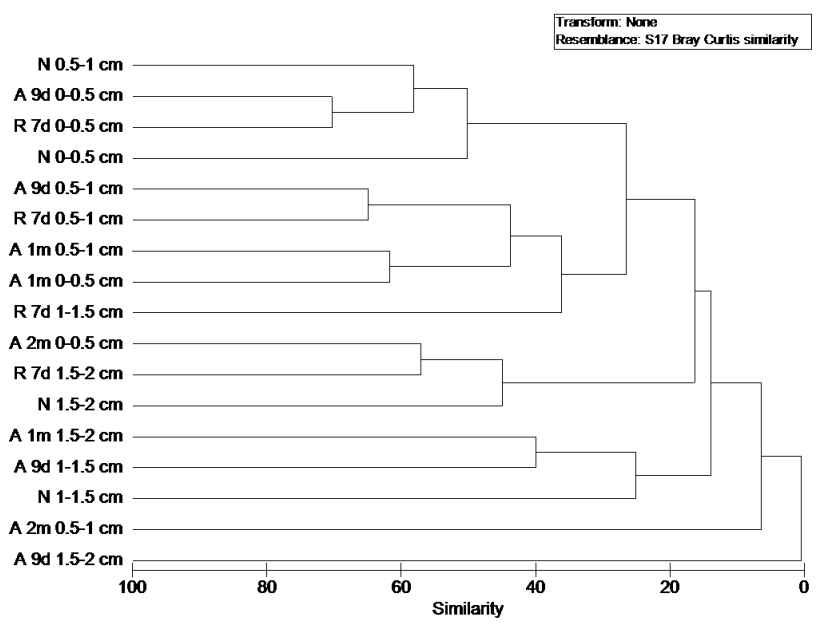

Fig. 6. Dendrogram of the Bray-Curtis similarity between samples (different treatments and different depths). $\mathrm{N}=$ normoxia, $\mathrm{A}=$ anoxia, $\mathrm{R}=$ recovery, duration of treatment: 7 days, 9 days, 1 month, 2 months). Triplicates averaged per depth layer.

of infauna. However, the measurements indicate no bioturbation activities in the 2-month and 10-month anoxic chambers, most likely due to low/no survival of meiofauna organisms (i.e. only 4 copepods alive after 2 months of chamber closure and no living copepods after 10 months). Importantly, the biggest mortality of animals was recorded at 1-month anoxia, clearly reflecting the peak in free sulfide hydrogen development (Metzger et al., 2013).

The copepod community composition differed substantially after various periods of anoxia, clearly demonstrating that anoxia governs community composition and that species-specific responses provide the baseline for the overall response. Analysing the copepod community at morphospecies level was therefore a rigorous and valid approach. The genera Pseudobradya, Heteropsyllus, Nitocrella and Longipedia showed a rapid mortality after 9 days of anoxia. The sensitivity of Pseudobradya was previously described by Modig and Ólaffson (1998) from the Baltic Sea. Representatives of the family Cletodidae, in contrast, were the most resistant, dominating the community in all anoxia treatments. In terms of morphology, species of the genera Cletodes, Stylicletodes, Enhydrosoma and Acrenhydrosoma are characterised by a slender habitus (Boxshall and Hasley, 2004). A slender body shape favours a fast turnover between ambient oxygen concentrations and copepod "internal" oxygen concentration, a process taking a few seconds in nematodes (Braeckman et al., 2013). Moreover, certain species may survive due to a reduced metabolism in suboxic conditions, and consequently have a longer lifespan (Braeckman et al., 2013). Cletodids are active mud-burrowers known mainly from shallow and sublittoral marine habitats, whereas some cletodid genera (e.g. Pyrocletodes, Mesocletodes) also occur in the deep sea (Coull, 1973; Boxshall and Hasley, 2004).
The latter points to an evolutionary line of adaptation to environments with low oxygen input. Both environments - shallow hypoxic coastal seas and deep sea - have in common that (1) oxygen in the interstitial spaces is a limiting factor, (2) fine-grained sediments dominate, and (3) the food input largely depends on allochthonous material. The genera Cletodes and Enhydrosoma that were identified as last survivors ( 2 months anoxia) in the present study are typical for muddy sediments (Hicks and Coull, 1983). In addition, the genus Asellopsis (family Laophontidae) survived up to 1 month of anoxia).

With increasing duration of anoxia, the overall density (per $16.6 \mathrm{~cm}^{2}$ ) dropped from $56.3 \pm 11$ (9 days' anoxia) to $16.7 \pm 5$ (1-month anoxia) but the dominance remained stable (Fig. 3c). This shows that no single species dominated the community. This differs from the diversity changes resulting from impacts such as eutrophication (Pearson and Rosenberg, 1978), fish farming, harbour pollution and sewage outfall (Vrišer, 1984; Moore and Bett, 1989; Sandulli and De Nicola, 1991; Mazzola et al., 1999; Gee, 2005; Tomassetti et al., 2009). Even if the family Cletodidae clearly dominated the communities in anoxic treatments, the Cletodidae species (6 species) were still equally represented by similar number of individuals (see stable evenness). As expected, the overall species richness decreased significantly from normoxia to 9 days' anoxia, to 1-month and 2 months' anoxia. This shows that certain species are more tolerant to both low oxygen and hydrogen sulfide (see Metzger et al., 2013). This helps interpret the recovery results of the copepod community soon after re-oxygenation (i.e. termination of the deployment): the surviving species have the potential to create a new community, because colonisation from outside was minimal.

The resilience of the remaining species, and thus community resilience, will largely depend on the reproductive success of these species. Our results did in fact show a substantial and rapid increase in the number of gravid females after 7 days of recovery. An organism's ability to increase its reproductive potential is known to be positively affected by extrinsic factors such as temperature, nutrition and salinity (see studies cited in Hicks and Coull, 1983). Our results indicate that also the increase in oxygen levels after anoxia stimulated the reproduction of copepods, in particular in Cletodidae. Even though they were not dominant in normoxia, they had the largest number of gravid females compared to other families in all treatments, including normoxia. Reproduction in harpacticoids generally occurs year-round (Hicks and Coull, 1983), but this suggests that our experiments coincided with their reproduction peak. In contrast, two sympatric species of Enhydrosoma (Cletodidae) were found to have a different cycle of seasonal abundance, with one having the peak in summer and the other in autumn and spring (Ivester and Coull, 1977). Independent of the overall density of Cletodidae, the number of gravid females increased considerably during recovery and was even higher than in the normoxic samples. According to Pearson and Rosenberg (1978), those species 
that have a potential to colonise empty spaces are those that can reproduce rapidly.

Auto-ecologically, this could mean that the most resistant species are also the most resilient because they adapt quickly to a changing environment, i.e. rise in oxygen level. In this case, resilience included rapid reproduction in order to establish a new population. Those species possessing this strategy will largely govern overall community resilience. In the present study, only species of the family Cletodidae survived and reproduced quickly. Elsewhere, the eggs of the planktonic Acartia bifilosa were also found to survive long periods of anoxia in dormancy, and started to hatch when the oxygen concentration rose $>0.17 \mathrm{~mL} \mathrm{~L}^{-1}$ (Katajisto, 2004). Fast reproduction rates have been reported for other copepod species (Hicks, 1984; Matias-Peralta et al., 2005; Zaleha and Busra, 2012, and references therein), but not in combination with a strong resistance to stressors such as anoxia. This is a unique and important combination in terms of the functional consequences of low biodiversity after an anoxic event. Also, only few surviving copepodites were found in anoxia, and slightly more in the recovery phase, pointing to their higher sensitivity versus adults. These results are supported by VeitKöhler et al. (2009), who found fewer copepodites and no nauplii in oxygen minimum zones.

In addition to rapid reproduction, harpacticoid copepods also need a specific feeding ecology to (1) cope with low oxygen levels and (2) gain sufficient energy as soon as anoxic conditions end. Several recent isotope measurements of Cletodidae (Cnudde, 2013) showed remarkably low and thus very depleted ${ }^{13} \mathrm{C}$ values (as low as $\delta^{13} \mathrm{C}=-30$ to $-40 \%$ ) . This suggests that Cletodidae are specialists feeding almost exclusively on chemoautotrophic bacteria. Additionally, this family may use a trophic pathway completely separate from the trophic cascade (typically depending on phototrophic primary production). Chemoautotrophic bacteria are mainly known from symbiosis with deep-sea animals (Cavanaugh, 1983; Jannasch and Mottl, 1985), but are also ectosymbionts on the benthic marine nematode Leptonemella in the North Sea (Riemann et al., 2003). These symbioses are interpreted as a strategy to migrate across the sulfur chemocline and may play a nutritional role for the host as well (Ott et al., 1991). Chemoautotrophic bacteria are also predominant in close proximity of intertidal macrofaunal burrows (Aller et al., 1983) and meiofaunal burrows (Reise, 1981). Here, the dependence on chemoautotrophic bacteria again interlinks our results with certain features of the deep sea. This makes specimens of the family Cletodidae - an evolutionary line represented in both the deep sea and shallow seas - clearly the "winners" of anoxia due to their specific feeding ecology and the reproductive success/rate as soon as oxygen levels increase again.

Beyond the Cletodidae, other harpacticoid copepod families were also found live after 7 days' recovery. In terms of composition, however, this community resembled that of 9 days' anoxia rather than of normoxia. We interpret this to reflect no species colonising from the nearby undisturbed, normoxic sediment. This is a surprising result, and may be due to a low motility of copepods from the nearby sediment and/or because the impacted sediment remained toxic for other species due to high sulfide concentrations (Bagarinao, 1992; Middelburg and Levin, 2009; Metzger et al., 2013). However, De Troch et al. (2013) showed that the reduced grazing pressure during anoxia promotes post-anoxia food availability (e.g. elevated concentrations of the fatty acid $16: 1 \omega 7$, typical for diatoms). This organic matter and the bacteria decomposing it represent an important food supply for organisms in the recovery phase. The recovery data suggest that only the surviving specimens benefited from this because the number of colonisers is negligible. Similarly, Langlet et al. (2013b) found an increased abundance of benthic Foraminifera in the 1-month anoxia as a consequence of increased food availability caused by the mortality of benthic fauna. We assume this is also linked to the reduced grazing pressure of survivors (see De Troch et al., 2013). Clearly, regardless of the mechanism and strategy, recovery in harpacticoid copepods and foraminifera was much more rapid than in the macrofauna (Blasnig et al., 2013).

In terms of population dynamics, the male/female ratio remained relatively stable, independent of oxygen level. This demonstrates similar survival levels in both sexes. Females, representing $>60 \%$, dominated in all treatments. Females also typically outnumber males in field samples (see Hicks and Coull, 1983 and references herein), and anoxia apparently does not influence this.

From a shorter (5 days) but similar experimental set-up in 2009, De Troch et al. (2013) concluded that harpacticoid copepod diversity on the family level was unaffected by anoxic conditions. The families Ectinosomatidae and Cletodidae were again most abundant in both normoxic and anoxic samples. The same authors also observed an increasing trend in relative abundance of Cletodidae in anoxia. At species level (this study), however, there were significant differences between normoxia and anoxia, possibly due to the lengthier anoxia (and to the approach used: identifying all copepods rather than a subsample, yielding higher diversity indices).

The copepod community also differed with depth. With increasing duration of anoxia, however, communities (diversity and density) typical for deeper layers of oxygenated sediments become similar to communities typical for higher layers of less oxygenated sediments. For example, the copepod assemblage in the second $(0.5-1 \mathrm{~cm})$ layer of normoxia was most similar to that from the first $(0-0.5 \mathrm{~cm})$ layer of 9 days' anoxia and 7 days' recovery. Additionally, the densities in the 0.5 to $1 \mathrm{~cm}$ depth layer under normoxia resemble those of the uppermost sediment layer in the A9d treatment. Finally, the $0.5-1 \mathrm{~cm}$ layer of 9-day anoxia (and 7 days' recovery) was similar to the top $(0-0.5 \mathrm{~cm})$ layer of 1-month anoxia. We interpret this with the vertical upward migration of copepods in the sediment as oxygen depletion continues. 
Interestingly, despite frequent oxygen depletion events in the northern Adriatic, the region is characterised by a high diversity of harpacticoid copepods (Vrišer, 2000a, b), one of the highest in European seas (Veit-Kohler et al., 2010). This highly diverse (in terms of sensitivity and tolerance) community is apparently able to survive shorter anoxic events relatively well and shows a high degree of resilience, whereby species of the family Cletodidae are best adapted to decreasing oxygen concentrations.

\section{Conclusions}

The in situ deployment of four plexiglass chambers for 9 days, 1 month, 2 months and 10 months allowed us to study in detail the response of harpacticoid copepods to anoxic events in the natural setting. After short-term (9 days) anoxia, several species (Pseudobradya sp. 2, Heteropsyllus sp. 1, Nitocrella sp. 1 and Longipedia sp. 2.) died and were therefore classified as the "losers" in anoxia. This led to a very rapid drop in harpacticoid density and species richness. As anoxia persisted, the relative abundance of Cletodidae increased, with some representatives surviving 1 and even 2 months. Based on the diversity patterns and stable evenness, all the species of this family were tolerant to anoxia (9 days and 1 month). This differs from the typical one-species communities after other impacts (e.g. eutrophication), underlining the strength of a species-based response analysis.

Combined with current knowledge on the ecology of Cletodidae, we conclude that these "winners" are very well adapted to anoxia in terms of (1) high resistance (see survival), (2) specific feeding ecology (stable isotope data, Cnudde, 2013) and (3) high resilience (rapid reproduction).

In terms of recovery, we recorded no significant increase in density but a slight increase in species diversity. This points to minimal colonisation from the nearby sediment: mainly the survivors guaranteed the recovery (based on the rapid increase in the number of gravid females). This will be important in the larger-scale anoxias that characterise most socalled dead zones. Our findings also underline that, in the recovery phase, a substantial amount of energy is allocated to reproduction.

\section{Supplementary material related to this article is available online at http://www.biogeosciences.net/11/281/ 2014/bg-11-281-2014-supplement.pdf.}

Acknowledgements. This study was financed by the Austrian Science Fund (FWF; project P21542-B17) and supported by the OEAD Bilateral Slovenian Austrian Scientific Technical Cooperation project SI 22/2009. The last author is a postdoctoral fellow financed by the Special Research Fund of the Ghent University (GOA project 01GA1911W). Thanks to T. Makovec, P. Steiner, I. Gallmetzer and A. Haselmair for diving support. The authors thank two anonymous reviewers for their constructive remarks that helped improve the manuscript.

Edited by: J. Middelburg

\section{References}

Aller, R. C., Yingst, J. Y., and Ullman, W. J.: Comparative biogeochemistry of water in intertidal Onuphis (Polychaeta) and Upogebia (Crustacea) burrows: temporal patterns and causes, J. Mar. Res., 41, 571-604, doi:10.1357/002224083788519722, 1983.

Anderson, M. J., Gorley, R. N., and Clarke, K. R.: PERMANOVA+ for PRIMER: Guide to Software and Statistical Methods, PRIMER-E Ltd, Plymouth, 2008.

Bagarinao, T.: Sulfide as an environmental factor and toxicant: tolerance and adaptations in aquatic organisms, Aquat. Toxicol., 24, 21-62, 1992.

Blasnig, M., Riedel, B., Schiemer, L., Zuschin, M., and Stachowitsch, M.: Short-term post-mortality scavenging and longer term recovery after anoxia in the northern Adriatic Sea, Biogeosciences, 10, 7647-7659, doi:10.5194/bg-10-7647-2013, 2013.

Boxshall, G. and Hasley, S. H.: An Introduction to Copepod Diversity, edited by: Series., T. R. S., Ray Society: London., 966 pp., 2004.

Braeckman, U., Vanaverbeke, J., Vincx, M., van Oevelen, D., and Soetaert, K.: Meiofauna Metabolism in Suboxic Sediments: Currently Overestimated, Plos One, 8, e59289, doi:10.1371/journal.pone.0059289, 2013.

Cavanaugh, C. M.: Symbiotic chemotrophic bacteria in marine invertebrates from sulphide-rich habitats, Nature, 302, 58-61, 1983.

Clarke, K. R. and Warwick, R. M.: Change in marine communities: an approach to statistical analysis and interpretation, 2nd ed., PRIMER-E, Plymouth, 2001.

Clarke, K. R. and Gorley, R. N.: PRIMER v6: User Manual/Tutorial, PRIMER-E, Plymouth, 2006.

Cnudde, C.: Trophic ecology of intertidal harpacticoid copepods, with emphasis on their interactions with bacteria, Ghent Unversity (UGent), 209 pp., ISBN 9789090278285, 2013.

Coull, B. C.: Meiobenthic Harpacticoida (Crustacea, Copepoda) from the deep sea off North Carolina IV, The families Cletodidae T. Scott and Ancorabolidae Sars., T. Am. Microsc. Soc., 92, 604-629, 1973.

Coull, B. C. and Vernberg, W. B.: Reproductive Periodicity Of Meiobenthic Copepods - Seasonal Or Continuous, Mar. Biol., 32, 289-293, 1975.

De Jonge, V. N. and Bouwman L. A.: A Simple Density Separation Technique for Quantitative Isolation of Meiobenthos Using the Colloidal Silica Ludox-TM, Mar. Biol., 42, 143-148, 1977.

De Troch, M., Vandepitte, L., Raes, M., Suàrez-Morales, E., and Vincx, M.: A field colonisation experiment with meiofauna and 
seagrass mimics: effect of time, distance and surface, Mar. Biol., 148, 73-86, 2005.

De Troch, M., Chepurnov, V., Gheerardyn, H., Vanreusel, A., and Olafsson, E.: Is diatom size selection by harpacticoid copepods related to grazer body size?, J. Exp. Mar. Biol. Ecol., 332, 1-11, doi:10.1016/j.jembe.2005.10.017, 2006.

De Troch, M., Roelofs, M., Riedel, B., and Grego, M.: Structural and functional responses of harpacticoid copepods to anoxia in the Northern Adriatic: an experimental approach, Biogeosciences, 10, 4259-4272, doi:10.5194/bg-10-4259-2013, 2013.

Diaz, R. J. and Rosenberg, R.: Spreading dead zones and consequences for marine ecosystems, Science, 321, 926-929, doi:10.1126/science.1156401, 2008.

Dytham, C.: Choosing and Using Statistics: A Biologist's Guide, Second ed., Blackwell Science, Oxford, 248 pp., 2003.

Emili, A., Acquavita, A., Koron, N., Covelli, S., Faganeli, J., Horvat, M., Žižek, S., and Fajon, V.: Benthic flux measurements of $\mathrm{Hg}$ species in a northern Adriatic lagoon environment (Marano and Grado Lagoon, Italy), Estuarine, Coastal and Shelf Science, 113, 71-84, doi:10.1016/j.ecss.2012.05.018, 2012.

Faganeli, J., Pezdič, J., Ogorelec, B., Herndl, G. J., and Dolenc, T.: The role of sedimentary biogeochemistry in the formation of hypoxia in shallow coastal waters (Gulf of Trieste, northern Adriatic), in: Modern and Ancient Continental Shelf Anoxia, edited by: Tyson, R. V., and Pearson, T. H., The Geological Society, London, 107-117, 1991.

Gee, J. M. and Warwick, R. M.: Preliminary-Observations On The Metabolic And Reproductive Strategies Of Harpacticoid Copepods From An Intertidal Sandflat, Hydrobiologia, 118, 29-37, 1984.

Gee, J. M.: Two new species of Bulbamphiascus Lang (Copepoda : Harpacticoida : Diosaccidae) from Scotland and the Isles of Scilly, with additional observations on $B$. denticulatus (Thompson), J. Nat. Hist., 39, 1961-1979, 2005.

Giere, O.: Meiobenthology:the Microscopic Motile Fauna of Aquatic Sediments, 2nd. rev. \& extended ed. Berlin ed., Springer, 2009.

Glud, R. N.: Oxygen dynamics of marine sediments, Mar. Biol. Res., 4, 243-289, doi:10.1080/17451000801888726, 2008.

Grego, M., Stachowitsch, M., De Troch, M., and Riedel, B.: CellTracker Green labelling vs. rose bengal staining: CTG wins by points in distinguishing living from dead anoxiaimpacted copepods and nematodes, Biogeosciences, 10, 45654575, doi:10.5194/bg-10-4565-2013, 2013.

Harris, R. P.: Feeding, Growth, Reproduction And Nitrogen Utilization By Harpacticoid Copepod, Tigriopus-Brevicornis, J. Mar. Biol. Assoc. UK, 53, 785-800, 1973.

Hicks, G. R. F. and Coull, B. C.: The ecology of marine meiobenthic harpacticoid copepods, Oceanogr. Mar. Biol., 21, 67-175, 1983.

Hicks, G. R. F.: Spatio-temporal dynamics of a meiobenthic copepod and the impact of predation-disturbance, J. Exp. Mar. Biol. Ecol., 81, 47-72, doi:10.1016/0022-0981(84)90223-5, 1984.

Ivester, S. and Coull, B. C.: Niche fractionation of two sympatric species of Enhydrosoma (Copepoda, Harpacticoida), Mickrofauna Meeresboden, 61, 137-151, 1977.

Jannasch, H. W. and Mottl, M. J.: Geomicrobiology of deep-sea hydrothermal vents, Science, 229, 717-725, 1985.

Janssen, A., Chevaldonnë, P., and Marténez Arbizu, P.: Meiobenthic copepod fauna of a marine cave (NW Mediterranean) closely resembles that of deep-sea communities, Mar. Ecol. Prog. Ser., 479, 99-113, doi:10.3354/meps 10207, 2013.

Josefson, A. B. and Widbom, B.: Differential Response Of Benthic Macrofauna And Meiofauna To Hypoxia In The Gullmar-Fjord Basin, Mar. Biol., 100, 31-40, 1988.

Justić, D., Rabalais, N. N., Turner, R. E., and Wiseman, W. J.: Seasonal coupling between riverborne nutrients, net productivity and hypoxia, Mar. Pollut. Bull., 26, 184-189, 1993.

Katajisto, T.: Effects of anoxia and hypoxia on the dormancy and survival of subitaneous eggs of Acartia bifilosa (Copepoda: Calanoida), Mar. Biol., 145, 751-757, 2004.

Koron, N., Ogrinc, N., Metzger, E., Riedel, B., and Faganeli, J.: Diagenesis and benthic fluxes of nutrients and metals during experimentally induced anoxia in the Gulf of Trieste (northern Adriatic Sea), Biogeosciences Discuss., 10, 11729-11755, doi:10.5194/bgd-10-11729-2013, 2013.

Kršinić, F., Carić, M., Viličić, D., and Ciglenečki, I.: The calanoid copepod Acartia italica Steuer, phenomenon in the small saline Lake Rogoznica (Eastern Adriatic coast), J. Plankton Res., 8, 1441-1464, 2000.

Lang, K.: Monographie der Harpacticiden, edited by: Ohlsson, H., Lund, 1682 pp., 1948.

Langlet, D., Baal, C., Geslin, E., Metzger, E., Zuschin, M., Riedel, B., Risgaard-Petersen, N., Stachowitsch, M., and Jorissen, F. J.: Foraminiferal species responses to in situ experimentally induced anoxia in the Adriatic Sea, Biogeosciences Discuss., 10, 1206512114, doi:10.5194/bgd-10-12065-2013, 2013a.

Langlet, D., Geslin, E., Baal, C., Metzger, E., Lejzerowicz, F., Riedel, B., Zuschin, M., Pawlowski, J., Stachowitsch, M., and Jorissen, F. J.: Foraminiferal survival after long-term in situ experimentally induced anoxia, Biogeosciences, 10, 7463-7480, doi:10.5194/bg-10-7463-2013, 2013b.

Matias-Peralta, H. F. M. Y., Shariff, M., and Arshad, A.: Effects of some environmental parameters on the reproduction and development of a tropical marine harpacticoid copepod Nitocra affinis f. californica Lang, Mar. Pollut. Bull., 51, 722-728, 2005.

Mazzola, A., Mirto, S., and Danovaro, R.: Initial Fish-Farm Impact on Meiofaunal Assemblages in Coastal Sediments of the Western Mediterranean, Mar. Pollut. Bull., 38, 1126-1133, 1999.

Mc Intyre, A. D. and Warwick, R. M.: Methods for the Study of Marine Benthos (IBP Handbook), 2nd ed., Methods for the study of marine benthos, edited by: Holme, N. A. and McIntyre, A. D., Blackwell Science Ltd, Oxford, 217-244, 1984.

Metzger, E., Langlet, D., Viollier, E., Koron, N., Riedel, B., Stachowitsch, M., Faganeli, J., Tharaud, M., Geslin, E., and Jorissen, F.: Artificially induced migration of redox layers in a coastal sediment from the Northern Adriatic, Biogeosciences Discuss., 10, 12029-12063, doi:10.5194/bgd-10-12029-2013, 2013.

Middelburg, J. J. and Levin, L. A.: Coastal hypoxia and sediment biogeochemistry, Biogeosciences, 6, 1273-1293, doi:10.5194/bg-6-1273-2009, 2009.

Modig, H. and Ólafsson, E.: Responses of Baltic benthic invertebrates to hypoxic events, J. Exp. Mar. Biol. Ecol., 229, 133-148, 1998.

Moore, C. G. and Bett, B. J.: The use of meiofauna in marine pollution impact assessment, Zool. J. Linn. Soc., 96, 263-280, 1989.

Murrell, M. C. and Fleeger, J. W.: Meiofauna abundance on the Gulf of Mexico continental shelf affected by hypoxia, Cont. Shelf Res., 9, 1049-1062, 1989. 
Ott, J., Novak, R., Schiemer, F., Hentschel, U., Nebelsick, M., and Polz, M.: Tackling the Sulfide Gradient: A Novel Strategy Involving Marine Nematodes and Chemoautotrophic Ectosymbionts P.S.Z.N.I: Mar. Ecol., 12, 261-279, 1991.

Pearson, T. H. and Rosenberg, R.: Macrobenthic Succession in relation to Organic Enrichment and Pollution of the Marine Environment., Oceanogr. Mar. Biol., 16, 229-311, 1978.

Powell, E.: Oxygen, sulfide and diffusion: why thiobiotic meiofauna must be sulfide-insensitive first-order respirers, J. Mar. Res., 47, 887-932, 1989.

R Development Core Team: R: A language and environment for statistical computing, R Foundation for Statistical Computing, Vienna, Austria, 2011.

Reise, K.: High abundance of small zoobenthos around biogenic structures in tidal sediments of the Wadden Sea, Helgolander Meeresun., 34, 413-425, 1981.

Riedel, B., Zuschin, M., Haselmair, A., and Stachowitsch, M.: Oxygen depletion under glass: Behavioural responses of benthic macrofauna to induced anoxia in the Northern Adriatic, J. Exp. Mar. Biol. Ecol., 367, 17-27, 2008.

Riedel, B., Pados, T., Pretterebner, K., Schiemer, L., Steckbauer, A., Haselmair, A., Zuschin, M., and Stachowitsch, M.: Effect of hypoxia and anoxia on invertebrate behaviour: ecological perspectives from species to community level, Biogeosciences Discuss., 10, 14333-14438, doi:10.5194/bgd-10-14333-2013, 2013.

Riemann, F., Thiermann, F., and Bock, L.: Leptonemella species (Desmodoridae, Stilbonematinae), benthic marine nematodes with ectosymbiotic bacteria, from littoral sand of the North Sea island Sylt: taxonomy and ecological aspects, Helgoland Mar. Res., 57, 118-131, 2003.

Sandulli, R. and De Nicola, M.: Responses of meiobenthic communities along a gradient of sewage pollution, Mar. Pollut. Bull., 22, 463-467, 1991.

Sokal, R. R. and Rohlf F. J.: Biometry, the principles and practice of statistics in biological research, edited by: W. H. Freeman and company, New York, 887 pp., 1995.

Stachowitsch, M.: Mass mortality in the Gulf of Trieste: the course of community destruction, Mar. Ecol., 5, 243-264, 1984.

Stachowitsch, M.: Anoxia in the northern Adriatic Sea: Rapid death, slow recovery, in: Modern and Ancient Continental Shelf Anoxia, Geological Society Special Publication ed., edited by: Tyson, R. V. and Pearson T. H., The Geoloical Society, London, 119-129, 1991.

Stachowitsch, M., Riedel, B., Zuschin, M., and Machan, R.: Oxygen depletion and benthic mortalities: the first in situ experimental approach to documenting an elusive phenomenon, Limnol. Oceanogr.-Meth., 5, 344-352, 2007.

Tomassetti, P., Persia, E., Mercatali, I., Vani, D., Marussso, V., and Porrello, S.: Effects of mariculture on macrobenthic assemblages in a western mediterranean site, Mar. Pollut. Bull., 58, 533-541, doi:10.1016/j.marpolbul.2008.11.027, 2009.
UNEP: Marine and Coastal Ecosystems and Human Wellbeing: a Synthesis Report based on the Findings of the Millennium Ecosystem Assessment, UNEP, 76 pp., 2006.

Veit-Köhler, G., De Troch, M., Grego, M., Bezerra, T. N., Bonne, W., De Smet, G., Folkers, C., George, K. H., Guotong, C., Herman, R., Huys, R., Lampadariou, N., Laudien, J., Arbizu, P. M., Rose, A., Schratzberger, M., Seifried, S., Somerfield, P., Vanaverbeke, J., Vanden Berghe, E., Vincx, M., Vriser, B., and Vandepitte, L.: Large-scale diversity and biogeography of benthic copepods in European waters, Mar. Biol., 157, 1819-1835, doi:10.1007/s00227-010-1454-0, 2010.

Veit-Köhler, G., Gerdes, D., Quiroga, E., Hebbeln, D., and Sellanes, J.: Metazoan meiofauna within the oxygen-minimum zone of Chile: Results of the 2001-PUCK expedition, Deep Sea Res. Pt. II: Topical Studies in Oceanography, 56, 1105-1111, 2009.

Vernberg, W. B. and Coull, B. C.: Multiple factor effects of environmental parameters on the physiology, ecology and distribution of some marine meiofauna, Cah. Biol. Mar., 16, 721-732, 1975.

Vopel, K., Dehmlow, J., Johansson, M., and Arlt, G.: Effects of anoxia and sulphide on populations of Cletocamptus confluens (Copepoda, Harpacticoida), Mar. Ecol.-Prog. Ser., 175, 121-128, doi:10.3354/meps 175121, 1998.

Vrišer, B.: Meiofaunal community structure and species diversity in the bays of Koper, Strunjan and Piran (Gulf of Trieste, North Adriatic), Nova Thalassia, 6, 5-17, 1984.

Vrišer, B.: Meiobenthic Harpacticoida (Copepoda) from the Southern part of the Gulf of Trieste (Northern Adriatic) I. List of taxa, Annales, Series Historia Naturalis, 19, 23-38, 2000a.

Vrišer, B.: Meiobenthic Harpacticoida (Copepoda) from the Southern part of the Gulf of Trieste (Northern Adriatic) II. Ecology and spatial distribution, Annales, Series Historia Naturalis, 19, 39-54, 2000b.

Wells, J. B. J.: An annotated checklist and keys to the species of Copepoda Harpacticoida (Crustacea) Zootaxa, New Zealand, 1568 pp., 2007.

Wetzel, M. A., Fleeger, J. W., and Powers, S. P.: Effects of hypoxia and anoxia on meiofauna: A review with new data from the Gulf of Mexico, Coastal and Estuarine Studies, Coastal Hypoxia: Consequences for Living Resources and Ecosystems, edited by: Turner, N. N. R. A. R. E., AGU, Washington, DC, 2001.

Zaleha, K. and Busra, I.: Culture of Harpacticoid Copepods: Understanding the Reproduction and Effect of Environmental Factors, in: Aquaculture, edited by: Muchlisin, Z. A., InTech, 390, ISBN: 978-953-307-974-5, doi:10.5772/28373, 2012.

Zuur, A. F., Ieno, E. N., and Elphick, C. S.: A protocol for data exploration to avoid common statistical problems, Methods in Ecology and Evolution, 1, 3-14, 2010. 